\title{
Understanding Dalit Literature: A Critical Perspective Towards Dalit Aesthetics
}

\author{
Priyanka Kumari ${ }^{1} \&$ Dr. Maninder Kapoor ${ }^{2}$ \\ ${ }^{1}$ Research Scholar, NIT Jamshedpur, Jamshedpur, Jharkhand. Email: priyanka.cuj@gmail.com, \\ https://orcid.org/0000-0002-7464-7080 \\ ${ }^{2}$ HOD NIT Jamshedpur, Jamshedpur, Jharkhand. Email: mkapoor.hum@nitjsr.ac.in, \\ https://orcid.org/0000-0002-5859-3879
}

\begin{abstract}
Indian literature has always been governed by classical norms. Literature has been divided into 'high culture' and 'low culture'. The non-Dalit writing revolves around 'rasa' and the motive is 'art for art's sake'. Dalit aestheticism is 'art for life's sake'. When certain forms and style are applied imitating Sanskrit poetics, Shakespearean language or Aristotle's 'Poetics', literature is considered to be following beauty parameters that are considered to be necessary for artistic pleasure. This kind of claim of holding traditional Indian aesthetics as a law book for all kind of literature cannot be validated. The assertion of mainstream aesthetics as aesthetics for pan India is bound to exclude truth of disregarded subjects. There is need for Dalit literature to follow alternative aesthetics as the writings are the real story of pain and survival. How can pain be read for the purpose of pleasure? In case of Dalit literature, the artistic yardsticks are not destroyed rather they are rejected. The traditional aesthetics will not be able to do justice with Dalit literature. Sharankumar Limbale writes "To assert that someone's writing will be called literature only when 'our' literary standards can be imposed on is a sign of cultural dictatorship" (Limbale, 2004, p. 107). This paper will be an attempt to discuss the need for alternative aesthetics to understand Dalit literature.
\end{abstract}

Keywords: Aesthetics, identity, realism, hegemony, culture.

\section{Introduction}

D. R. Nagaraj describes Dalit literature as a literature of decultured Dalits whose culture has been ignored and whose writings have articulated a demand for rights and entitlements in a democracy. Though Dalits are an integral part of Indian society, their tradition, culture, and problems have been deliberately excluded from the grand narrative of Indian history and civilization. Unable to find its place in Indian canonical literature, Dalit literature has created its own space. Dalit literature has power to bring transformation therefore it is also called revolutionary literature. Arjun Dangle affirms this idea by saying "Dalit is the name of total revolution; it is revolution incarnate" (1999, p. 289). The main motive of writing Dalit literature is to snatch back the Dalit identity, to valorise their experience, and thereby to provide a platform by way of which their existence would be acknowledged. 
Dalit writings are largely influenced by Buddha, Periyar, Phule, Ambedkar and the Dalit Panther movement which in turn was inspired by the Black Panther movement and other western ideas that aimed at social justice and mutual respect vitally necessary for an ideal and democratic society. This form of writing forged a cultural, political, and social identity for this deprived class by reimagining the place of Dalits and their experiences in this modern era. The perspective of Dalit writers was never taken in a positive light, and never recognised as a national problem that needs redressal. All these factors marked Dalit writings as separate and different.

The aesthetics of Dalit literature is a theory that governs Dalit literature. It retrieves the stories of Dalits from the threat of erasure and ensures their exposure through articulate assertion. On all popular platforms be it media, literary works, or cinema, their stories are either muted, overlooked or misrepresented. This aesthetics also defamiliarizes the popular notion on Dalits in mainstream literature through portraying the stories of Dalits by applying their own aesthetics in different genres of literature. This brings a totally new discourse that is not familiar in the world of literature but is representation of true stories i.e., closer to society. With this, the power structure that has been long applied to all spheres of life is now challenged. Dalit literature plays a major part in breaking the hegemonic relations present in social, cultural, economic, religious, and literary configurations. Understanding literature, aesthetics, history, and philosophy through an entirely different lens has now become possible. Alok Mukherjee, the translator of Sharankumar Limbale's "Towards an Aesthetic of Dalit Literature" (2004) in the translator's introduction of this book says:

"Dalits are an important political and social force in India. Their literary and critical writings constitute a major challenge to, and questioning of, the theorizing about Indian politics, society, culture and literature by intellectuals from upper caste Hindu and other dominant communities, and by non- Indians. To fail to pay attention to this challenge and questioning, is to engage in a hegemonic discourse that excludes the realities and experience of nearly a quarter of the country's people" (p. vii).

\section{Discussion}

Mainstream Indian literature follows the triadic concept of 'Satyam' the truth, 'Shivam', the sacred and 'Sundaram', the beautiful but in case of Dalit literature this view is discarded. How can a person's birth in a certain community be associated with the sins of previous birth? Can the injustices and atrocities inflicted on humans because of their caste be considered as sacred? How can learning or property kept for only certain sects be considered beautiful. The purpose of aesthetics in Dalit literature is to advocate for equality, liberty, justice and fraternity for the most depressed class in society. If one understands all these terms as the essence of human rights then only one can understand Dalit literature. Non-Dalit writing revolves around 'rasa' and the motive is 'art for art's sake'. Dalit aestheticism is 'art for life's sake'. The language used by Dalit writers discards the artistic way of presentation which assures pleasure to readers.

Traditional aesthetics which is also the aesthetics for "standard" literature has tendency to exclude the disregarded subjects. One kind of style cannot be fixed as lawbook for pan India. Each kind of genre of literature has its own way of representation which may also depend on time 
in which it has been recorded. Art is not permanent; it keeps changing with society and culture. With a diverse culture and tradition there is also a diverse genre of literature where taste may vary among people. There should be room for new literary trends so that the yardsticks of literature do not become stagnant. According to V.L Kulkarni "even if the narrative in a Dalit text appears ordinary, it still has the undoubted capacity to convey pain to the readers." (Kulkarni, 1978, as cited in Limbale, 2004). Limbale also questions- why cannot giving 'extraordinary pain' be considered as a standard of literature if literature providing 'extraordinary pleasure' is considered beautiful and standard. The need to understand meaning is far more important than form and technique. It is the true portrayal of Dalit lives which adds literary value to Dalit literature, but sadly often is dismissed as 'artless.' According to writers like N S Phadke, the life of Dalits and events that follow in their life are not worthy of showcasing through novels. He says that the kinds of contexts and events that are needed to add colour to a novel are not found in Dalits' lives' (Phadke, as cited in Limbale, 2004). These writers believe the protagonist of a novel should have a majestic life and experience which cannot come from Dalit life as their stories will also have hut like structures as their life. The work of literature or art is not limited to showcase lives of only majestic people or sections who enjoy royal lifestyle. All lives matter and are significant and capable of representation in any art form. Importantly, the twenty-first century demands for justice and voices for its rights. This becomes evident with the beginning of Dalit movements and emergence of Dalit literature and a rapid rise in its numbers. There are so many writers like Arun Sadhu and Madhu Mangesh Karnik who have written novels on Dalit life. Not only novels, there are other genres like poetry, short stories, autobiographies, plays that have tried to tell the story of the subalterns, the most deprived section of Indian society so that their issue becomes familiar with not only Dalits but also savarnas to whom translation helped to bring these literatures within the purview of the entire globe. Savarna writers like Premchand, Mulk Raj Anand, Mahasweta Devi, Girish Karnad, T.S Pikkai have written phenomenally well and have made the problems of Dalits acquainted with the mainstream. Their portrayal however is superficial, as they either glorify the Dalit characters portraying them as heroes or they paint them in words to evoke sympathy for them. Their condition is thought to be because of God's will, or because of their Karma and they are thought to be different from the twice born. The actual story which alone has been able to do justice to the Dalit reality remains compressed. Often their representation of Dalit life is shifted from caste to materiality. This can be explained through the excerpts taken from the book "Caste and Dalit Lifewords" written by Debjani Ganguly:

"My attempt to read caste as discourse does not automatically connote a disavowal of the materiality of caste, a disavowal of the way in which its imbrication in South Asian institutional structures affects the lived reality of the people. The pain of Dalits is palpable and embodied. I cannot presume to reduce it to a text or even to a series of texts, or even to discourse pure and simple. Its corporeal presence will forever cast an anguished shadow over anything one writes, or has written, about it. At the same time, it is also a pain that has long, complex and overlapping histories, histories about which there is even today hardly any consensus, notwithstanding the tomes that have been devoted to their analysis." (2008, p. 10)

These writings clearly indicate that while "savarna" writers do attempt to show their sympathetic attitude toward Dalits, they are unable to comprehend the Dalit craving for a 
dignified life. It is not only materialistic fulfilment that can change the condition of Dalits in India, but also a sincerely humane treatment that must replace upper class disdain if Dalit self -respect is to be salvaged and a certain degree of normalcy restored to their lives. This insistence on equating material things with caste related problems creates confusion between 'caste' and 'class'. The attitude of mainstream writers and upper-caste critics to view the Dalit present and past through the lens of patronising sympathy and to compensate age-old wrongdoing through social and material benefits alone leaves much to be desired. Material gain cannot be compensation for centuries of injustice. Human issues should be the prime concern of writers, and this is possible only when the writers themselves are Dalit. There are several other aspects of Dalit life that are inadequately discussed, for example their culture, food, religion, philosophy, history, and gender. The main purpose of discussing Dalit literature as an alternative way of understanding reality is to bring social justice and equity through literature. Nagaraj, a Dalit cultural critic, is against the state agenda to unify caste, class and religion. He says:

"I cannot agree with the ideologically perceived and politically posited unity between the realms of dignity, religiosity, and entitlements. Historically, this unity is wrong, it dispirits cultural imaginations, it is politically self-defeating and short sighted. Further, a certain notion of power and authority operates behind such a Unitarian vision wherein temporal structures are considered absolute, and material being is considered the only state of authentic experience." (2010, p. 187-188)

Nagaraj is gesturing towards the Brahmin mind as the chief perpetrator of critical works and writings on Dalit literature that have always defended the hegemonic caste division. Therefore, Nagaraj says "we need to re-create the contours of Dalit imagination by mapping the terrain of the Brahmin mind." (p. 187-88). Now we need to re-imagine the Dalit story. Stories must be written by Dalit authors to initiate an alternative vision. Dalit writings have always showcased an alternative way of representing Dalit lives. Though upper caste writers discussed the lack of opportunity for vertical mobility because of the repressive social order, these talks were superficial and never tried to understand the victims' perspective. Lack of authenticity is another shortcoming noticeable in writings of non-Dalit writing on Dalit life. Their sensitivity is often doubted as they have no first- hand experience of the actual pain of being a Dalit. Tarachand Khandekar calls Dalit writings as "letters of their own blood" (1994, p. 6).

Another objection to upper caste writing on Dalit issues is that their stories always glorify the caste Hindu character. Even if they are portrayed in a bad light in the beginning, the end of the story will move towards bringing about their 'change of heart'. The lower caste characters will be able to arouse sympathy in the mind of readers but will never have a voice of their own and even if they are portrayed as strong characters, they will be romanticized and portrayed as larger than human.

It is the way of representation that distinguishes Dalit literature written by Dalits from that written by non-Dalit writers. There are certain emotions like anger, pity, nostalgia, melancholy unique to writings about Dalits by Dalit writers. The language used is coarse and piercing in deliberate defiance to savarna tradition and urgently provoked by personal anguish and rejection. The use of the native language of the speaker adds sharpness to the voice. These emotions are often listed in the wrong proportion by savarna writers which make their representation 
inadequate and damaging. Nagaraj criticizes other communities writing on Dalits by saying "In creative writings such babysitting for other groups and classes is very awkward." (p. 61). Dalit narrative is actual experience lived and felt. This makes their work real and in its true form, unadulterated. Their language is therefore crude, coarse, unrefined like their actual life which is filled with poverty, ignorance, brutality. They feel that the refined language and euphonic representation of mainstream writers will pollute the true way of life Dalits live. There are many layers of Dalit life which can be brought before readers only through people of the same community, and if not, many contours may remain unexplored.

The plain and simple language used by Dalit writers to express their story is often criticised for lacking in artistic beauty. The very language they speak at their home, in their village, with acquaintances is also the mode of their creativity. For example, Namdeo Dhasal, widely known for his work 'Golpitha', has used words and slang that are routinely spoken in the streets of Kamathipura, a place where he grew up. When a Dalit writer writes, it is not only about caste. He depicts culture, dialect, slang, class, gender, region and so many other things. The forms and structures are also questioned for not being 'literary'. The Dalit technique is unique and does not require to follow the traditional aesthetics of literature but subscribes to an alternative aesthetics which sets a realistic tone. The non-acceptance of Dalit language shows the caste and class difference present in society. The language becomes too naive for the middle class and high class educated people, and even when they understand it, they often get offended by such usage. Laura Brueck in her critical work "Writing Resistance: The Rhetorical Imagination of Hindi Dalit Literature" calls for close attention to the Dalit writing styles. She says the choice of their language and style "allows for a more careful understanding of the interstices of Dalit activism, "consciousness" and literary expression" (2014, p. 8). She feels the choice of writing technique and language is effortless but also intentional as it challenges the dominant method in writing practiced by upper caste writers. It is through the choice of their native language, way of expression, and vocabulary that they are able speak truth to the power of the centre and assert their unique identity.

Most Dalit writers tend to choose the language they speak as a medium to write. There are Dalit texts available in so many languages and dialects, depending on the region in which they are written. It is through translation that these texts travel from one region to another. The English translation of this literature has not only made Dalit texts available to the whole of India, but it has also brought global recognition to the problems of caste. In her article 'Does Translation Empower a Dalit Text?' K. Suneetha Rani, says "the empowerment of Dalit literature has been achieved already when a Dalit writer has articulated his/her experiences and feelings which come from the deep sense of pain and shame... (2007, p. 63). It is an acknowledged fact that translation has so many negative connotations attached to it as the process can take away its real meaning. The way of expression mirrors culture and class, and translation often results in misinterpretations. In the case of Dalit literature, it has both negative and positive aspects. The process of translation has made it possible to question the glorious history of India which had painted a glamorous picture of it as "a bird of gold". The alternate or parallel history was conveniently ignored. The stories which were not of great people and warriors had no place. However, when translations became available, a better understanding of India through the lens of not only the dominant, but also the dominated became possible, thus, making the society dialogical. 
Though Dalit literature emerged much earlier, the Dalit Panther movement in 1970 saw a sudden increase in various genres of Dalit literary works like plays, novels, and autobiographies. All these works have challenged the traditional way of treating Dalit life as an unending saga of only pain and misery. For the first time, so many writers from this community took the pen in their own charge. Holding a pen to write their own story itself is an act of resistance. They painted their life in their own unique way, wishing to reach out to a larger audience of not only their own community but also beyond. In the process, they demonstrated their bold rejection of savarna condescension and overt sympathy. They required neither sympathy nor an overdose of glorification. All they asked for was a life of dignity, self-respect, and the right to be treated as not less than human beings. Dalit writers talk of all the factors that have repressed their growth like untouchability, poverty, caste oppression, class difference, gender trouble etc. The motive behind their writing is the demand for a casteless society. This leads them to challenge Brahminical power relations that act as catalysts in maintaining caste hegemony humiliating Dalits to the lowest level in the hierarchy of power.

Dalit literature began with Poetry as its dominant form. Even though the poet was writing from his personal experience of life, he became representative of the life of thousands of people going through similar distress. In a poem, a certain lyrical style and rhythm has to be followed, but these qualities called for a compromise in the essence of the message conveyed. This kept Dalits away from idioms, selection of rhythmic words and style and fake expression. As a result, their poetry was not counted as 'standard'. Simple words were selected without giving much importance to the language considered appropriate for poetry. This raised questions on the efficiency of Dalit poets to write good poetry. Only natural words, expressions, and spontaneous feelings could do justice to this genre as words of revolution demand truth. The questioning of literary standards is futile as the utterance in the poem is the only word capable and adequate to capture their struggle for life. Even the "standard" cannot be questioned as the poet followed a completely different aesthetic - an aesthetic that insisted on pure and plain language to showcase their education, dwelling, and miserable life. For example, 'Golpitha' by Namdeo Dhasal through simple words talks of the pain and pleasure of the sex-workers of Kamathipura in Mumbai - one of the largest businesses of prostitution in India. Dilip Chitre, a Marathi poet and translator of 'Golpitha', says of Dhasal's work that "his poetry contains, unlike theirs, large chunks of a real and dirty world by the have-nots and speaking their many slangs" (Chitre, 1982, as cited in Bhagavan and Feldhaus, 2011). This type of depiction of Dalits is the demand of the situation and it cannot be presented through other ways. Literary devices, flowery language, rhythm will hamper the meaning, originality and intensity. This applies to not only poetry but to all genres of Dalit writing. Dalit writing has to be read and written differently. Ramkrishnan says "the body of writing is not amenable to description and interpretation along purely literary, formalistic lines. The Dalit writers succeed in emphasizing the fact that the dominant view is the view of the dominant" (1995, p. 97). In the process of writing about their experiences and observations, Dalit writers are getting recognition as rebels against the literary limitations imposed and enforced by external forces.

After poetry, autobiographies became the dominant Dalit genre. Writing their stories is itself an act of resistance because for the first time Dalits took the pen in their own hands to fight for themselves through literature. They began telling the stories of their own survival and the turbulence they experienced in the process. It was only after the Independence of India and with 
the spread of education for all, that Dalits began writing. This genre also received the wrath of upper-caste critics and writers for not following the 'standard' aesthetics. The technique of autobiographies was entirely different from existing norms. There are even some autobiographies that are orally recorded and then penned. Dalit autobiographies cannot be similar to general autobiographies because of various reasons. Writing autobiographies here is like breaking the age-old silence. In almost all Dalit autobiographies we find a sense of chaos, unfulfillment, and insecurity even after the achievement of a top job position. There is fear of losing social position and fear of facing discrimination because of the caste they are born into. There is no freedom from caste. In other autobiographies, written by savarna writers there is a sense of calmness and fulfilment. The increase in the number of autobiographies being written is indicative of the refusal to be a mute spectator to routine ignominy. It is important to read Dalit literature by Dalit authors to know the authentic story. Dalit autobiographies serve the purpose best. It is only through Dalit autobiographies that one can understand the true mental, physical, and economical condition of this depressed class and their culture. Autobiographies do not embroider the truth.

In recent times, Dalit life has found an outlet through fiction in the form of novels, plays and short stories. However, they are fewer in number. All these genres of Dalit literature have enabled the actual voice of a section of society suffering caste trouble to be heard.

The aesthetics of the literature of any society is also dependent on its mythology. These stories are retold orally and also in written form. For a large section of the population, it becomes factual truth while other sceptical sections always seek a reason for what they hear. In India, the caste narrative constantly alludes to myth in the depiction of Dalit characters. The binary presentation of Dalits and Adivasi as evil and their counterpart as good made it necessary to craft an alternative aesthetics. Deconstruction of these kinds of myths is essential as a counter to the portrayal of the indigenous population as demonic. The depiction of Karna and Eklavya as heroes bearing lot of suffering is applauded in popular writings. However, when a Dalit writer reconstructs these characters, they are imbued with a distinct Dalit consciousness. Baburao Bagul points out that non-Dalit writing manifests nothing but mythical values and consciousness. This is the reason there is the need to read and write Dalit literature with Dalit consciousness.

\section{Conclusion}

The motive of writing Dalit literature is not artistic pleasure, but the desire to bring the marginal to the centre. Its canvas reaches much beyond caste inequalities and injustices running generation after generation. Realism is the key of Dalit literature. The savarna writers have always questioned the shaundaryashastra of Dalit literature and the yardstick against which it must be judged. They talk of tradition and culture, but they forget that Dalits too have their own culture which may be different from theirs, as their circumstances are not the same. Another problem that savarna writings carry is the absence of sociological yardsticks. When Dalit writers write Dalit literature, they write from a Dalit consciousness. Dalit consciousness refers to the understanding of the writers of their own Dalit identity. The motive behind such writing is to make the readers aware of the prevailing evil system, to make them understand the Dalit struggle, and to bring about a revolution through their writing. "The very act of writing is an act of resistance as they speak the truth that has been continuously ignored, challenged or silenced" (Rajkumar, 2019, p. 74) 
8 Rupkatha Journal, Vol. 13, No. 4, 2021

\section{References}

Brueck, Laura. Writing Resistence: The Rhetorical Imagination of Hindi Literature. New York: Columbia, 2014. Print.

Chitre, Dilip. "The Architecture of Anger: Namdeo Dhasal's "Golpitha"." Journal of South Asian Literature (1982): 93-95. Print.

Dangle, Arjun. Poisoned Bread:Translations From Modern Marathi Dalit Literature. Mumbai: Orient Longman, 1994. Print.

Dunna, Raja Rao. "Dalit Aesthetics Versus Mainstream Aesthetics: A Comparative Perspective." JETIR (2018): Volume 5, Isssue11.

Feldhaus, Manu Bhagavan and Anne. Claiming Power from Below: Dalits and Subaltern Questions in India. New Delhi: Oxford, 2011. Print.

Gajarwala, Jatin Toral. Untouchable Fictions: Literary Realism and the Crisis of Caste. New York: Fordham UP, 2013. Print.

Ganguly, Debjani. Caste and Dalit Lifewords: Postcolonial Perspectives. New Delhi: Orient BlackSwan, 2008. Print.

Khandekar, Tarachand. "'Literature of Revolt and Resurgence.' " The First Al/ India Dalit Writers Conference: A Commonwealth Volume. Ed. Bojja Tharakam. Hyderabad: Dr. B.R. Ambedkar Memorial Trust, 1994. Print.

Knappert, Jan. Indian Mythology. London: Diamond Books, 1995. Print.

Kothari, Rita. Translating India. New Delhi: Cambridge, 2006. Print.

Kumar, Ghanshyam. "Lalit Aesthetics and Dalit Aesthetics." International Standard Serial Number (2009): Volume.7. Issue 2. Print.

Kumar, Raj. Dalit Literature and Criticism. hyderabad: Orient Blackswan Private Limited, 2019. print.

Limbale, Sharan Kumar. Towards an Aesthtics of Dalit Literature. Hyderabad: Orient longman, 2004. print.

Nagraj, D.R. The Flaming Feet and Other Essays: The Dalit Movement in India. Ranikhet: Permanent Black, 2010. Print.

Ramakrishnan, E.V. Making it New: Modernism in Malyalam, Marathi and Hindi Poetry. Shimla: Indian Institute of Advanced Study, 1995. Print.

Rani, K. Suneetha. "'Does Translation Empower a Dalit Text"." Language and Forum (2007): 54-64. Print.

Rao, Anupama. "The word and the world: Dalit aesthetics as a critique of everyday life." Journal of postcolonial writing (2017): 147-161.

Satyanarayana, K. "The Political and Aesthetic Significance of Contemporary Dalit Literature." The Journal of Commonwealth Literature (n.d.): 1-16. Web. 